\title{
The use of ultra-dense array CGH analysis for the discovery of micro-copy number alterations and gene fusions in the cancer genome
}

\author{
Ewa Przybytkowski, Cristiano Ferrario, Mark Basik*
}

\begin{abstract}
Background: Molecular alterations critical to development of cancer include mutations, copy number alterations (amplifications and deletions) as well as genomic rearrangements resulting in gene fusions. Massively parallel next generation sequencing, which enables the discovery of such changes, uses considerable quantities of genomic DNA (> 5 ug), a serious limitation in ever smaller clinical samples. However, a commonly available microarray platforms such as array comparative genomic hybridization (array CGH) allows the characterization of gene copy number at a single gene resolution using much smaller amounts of genomic DNA. In this study we evaluate the sensitivity of ultra-dense array CGH platforms developed by Agilent, especially that of the 1 million probe array (1 M array), and their application when whole genome amplification is required because of limited sample quantities.

Methods: We performed array CGH on whole genome amplified and not amplified genomic DNA from MCF-7 breast cancer cells, using $244 \mathrm{~K}$ and $1 \mathrm{M}$ Agilent arrays. The ADM-2 algorithm was used to identify micro-copy number alterations that measured less than $1 \mathrm{Mb}$ in genomic length.

Results: DNA from MCF-7 breast cancer cells was analyzed for micro-copy number alterations, defined as measuring less than $1 \mathrm{Mb}$ in genomic length. The 4-fold extra resolution of the $1 \mathrm{M}$ array platform relative to the less dense $244 \mathrm{~K}$ array platform, led to the improved detection of copy number variations (CNVs) and micro-CNAs. The identification of intra-genic breakpoints in areas of DNA copy number gain signaled the possible presence of gene fusion events. However, the ultra-dense platforms, especially the densest $1 \mathrm{M}$ array, detect artifacts inherent to whole genome amplification and should be used only with non-amplified DNA samples.
\end{abstract}

Conclusions: This is a first report using $1 \mathrm{M}$ array CGH for the discovery of cancer genes and biomarkers. We show the remarkable capacity of this technology to discover CNVs, micro-copy number alterations and even gene fusions. However, these platforms require excellent genomic DNA quality and do not tolerate relatively small imperfections related to the whole genome amplification.

\section{Background}

Recent advances in genomics have dramatically increased our capacity to analyze both normal and cancer cells, revealing a multitude of changes in genomic DNA, such as mutations and copy number alterations (CNAs). One of the most exciting discoveries of the last 5 years has been the discovery of the important role of DNA copy number variations or polymorphisms (CNVs) in determining predisposition to diseases such

\footnotetext{
* Correspondence: markbasik@gmail.com

Department of Oncology, Lady Davis Institute, Sir Mortimer B. Davis Jewish General Hospital, McGill University, Montreal, Quebec, Canada
}

as autism, HIV infection and glomerulonephritis [1-4]. Moreover, the characterization of molecular alterations specific to cancer has enabled the discovery of novel predictive and prognostic biomarkers, which are becoming an integral part of the development of novel targeted therapeutics in cancer. Molecular alterations critical to cancer therapeutics include CNAs such as gene amplifications and deletions as well as genomic rearrangements resulting in gene fusions. DNA amplifications have been shown to contain important druggable oncogenes, such as the genes encoding for the HER2 and EGF receptors $[5,6]$. The discovery of chromosomal translocations in solid tumors, such as the one involving the $A L K$ gene

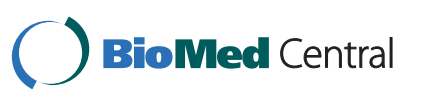

(c) 2011 Przybytkowski et al; licensee BioMed Central Ltd. This is an Open Access article distributed under the terms of the Creative Commons Attribution License (http://creativecommons.org/licenses/by/2.0), which permits unrestricted use, distribution, and reproduction in any medium, provided the original work is properly cited. 
resulting in a novel oncogenic fusion protein in lung adenocarcinoma, have also led to the development of very promising novel therapies directed against these changes $[7,8]$. Although massively parallel next generation sequencing enables the discovery of such changes [9], this technology remains expensive, requires extensive bioinformatics support, uses considerable quantities of genomic DNA (> $5 \mathrm{ug}$ ), and is not easily accessible. On the other hand, a commonly available microarray platform such as array comparative genomic hybridization (array CGH) allows the characterization of gene copy number at a single gene resolution using as little as $0.5 \mu \mathrm{g}$ of genomic DNA [10]. Such sensitivity becomes important when one considers that genomics technologies are increasingly being applied to minute tumor samples such as those obtained from biopsies. Moreover, the recent development of the one million (1 M) probe array CGH platform by Agilent offers an ultra-high $(2.1 \mathrm{~kb})$ resolution definition of DNA copy number alterations. The potential advantage of such ultra-high resolution is the better delineation of DNA breakpoints at DNA copy number alterations as well as the identification of very small, focal CNAs and CNVs.

However, several challenges are posed by the use of such technologies in ever smaller clinical samples. First, how small are the micro-CNAs that can be reliably detected by ultra-high resolution microarrays? Second, can they reliably detect small CNAs using the minute quantities of DNA (e.g. 10-50 ng) extracted from small biopsy samples? In order to obtain enough DNA from such samples, one usually performs whole genome amplification (WGA) of DNA extracted from these samples $[11,12]$. Does the amplification process introduce artifacts that can confound the analysis of data generated by such high sensitivity technologies $[13,14]$ ? As array CGH is increasingly being performed in clinical "biomarker" studies, it is necessary to have a clear understanding of the limitations of this technology in these contexts. To this end, we performed a study to answer two questions: how much sensitivity is gained by using Agilent's $1 \mathrm{M}$ probe array CGH over the less sensitive $244 \mathrm{~K}$ arrays, and, can one safely use whole genome amplification of DNA for these array $\mathrm{CGH}$ platforms?

Using DNA from the MCF-7 breast cancer cell line, we found that the 4-fold extra resolution of the $1 \mathrm{M}$ array platform led to the improved detection of CNVs and intra-genic CNAs in the MCF-7 cell line, which were mostly less than $100 \mathrm{~Kb}$ in genomic length. Interestingly, DNA breakpoints that signal the presence of genomic rearrangements could be detected and better delineated using the ultra high-resolution platform. However, combining the $1 \mathrm{M}$ Agilent array CGH platform with whole genome amplification of DNA results in the appearance of many artifacts, which, although frequently distinguishable from true CNAs by the naked eye, lead to the calling of many spurious CNAs when a commonly used CNA detection algorithm is used. Thus ultra-high resolution methods of detecting CNAs must be used with great caution when WGA is required for the analysis of samples with limiting quantities of DNA.

\section{Results and discussion}

The detection of micro-copy number alterations using ultra-high resolution array $\mathrm{CGH}$

To assess the sensitivity of ultra-dense array CGH for the detection of small copy number alterations (CNAs) in the genome we analyzed DNA from MCF-7 cells with $244 \mathrm{~K}$ and $1 \mathrm{M}$ array CGH from Agilent. The array CGH data obtained with both platforms were remarkably reproducible at the genomic and chromosomal levels. All large chromosomal aberrations were reliably identified with both platforms (Figure 1A and 1B). We then focused on very small CNAs or "micro-CNAs", defined as those measuring less than $1 \mathrm{Mb}$ in genomic length. To screen for these "micro-CNAs", we used the ADM-2 algorithm developed by Agilent and included in the Agilent Genomic Workbench for CGH analysis. Table 1 lists all 39 such CNAs classified by size, which were found in the MCF-7 genome with the ADM-2 algorithm in both array platforms and includes 24 copy number gains (amplifications) (62\%) and 15 copy number losses (deletions) (38\%). Three such micro-CNAs found on chromosome 3 are shown in Figure 1B. Two of these contain a single gene, while the third one, which is the smallest CNA detected by the $1 \mathrm{M}$ array $\mathrm{CGH}$, measuring only $8 \mathrm{~Kb}$ in genomic length, contains no gene (Figure $1 C$ ). In comparison, the smallest CNA found with the $244 \mathrm{~K}$ platform measured $64 \mathrm{~Kb}$ in genomic length (CNA \#8 in Table 1). Thus, the performance of both platforms reflected to some extent the relative spacing of probes on the arrays (i.e. the 4-fold greater resolution of the $1 \mathrm{M}$ arrays).

Of these 39 micro-CNAs, 15 (38\%) were found only using the $1 \mathrm{M}$ platform, and 11 of these were smaller than $100 \mathrm{~Kb}$. Indeed, only 2 of the 13 micro-CNAs smaller than $100 \mathrm{~Kb}$ were detected by the $244 \mathrm{~K}$ array, while all but 3 of the 26 micro-CNAs greater than 100 $\mathrm{Kb}$ in length were detected by both arrays, suggesting that the threshold of sensitivity for the detection of small CNAs for the $244 \mathrm{~K}$ array platform is about $100 \mathrm{~Kb}$ in chromosomal length. Four CNAs larger than $100 \mathrm{~Kb}$ were not detected by the $244 \mathrm{~K}$ arrays in our experiments. Two of these were low-level copy number changes, and thus not as likely to be called by the ADM-2 tool, and the other two were better delineated at the higher resolution provided by the $1 \mathrm{M}$ arrays. Of the 15 micro-CNAs detected only by the $1 \mathrm{M}$ array 


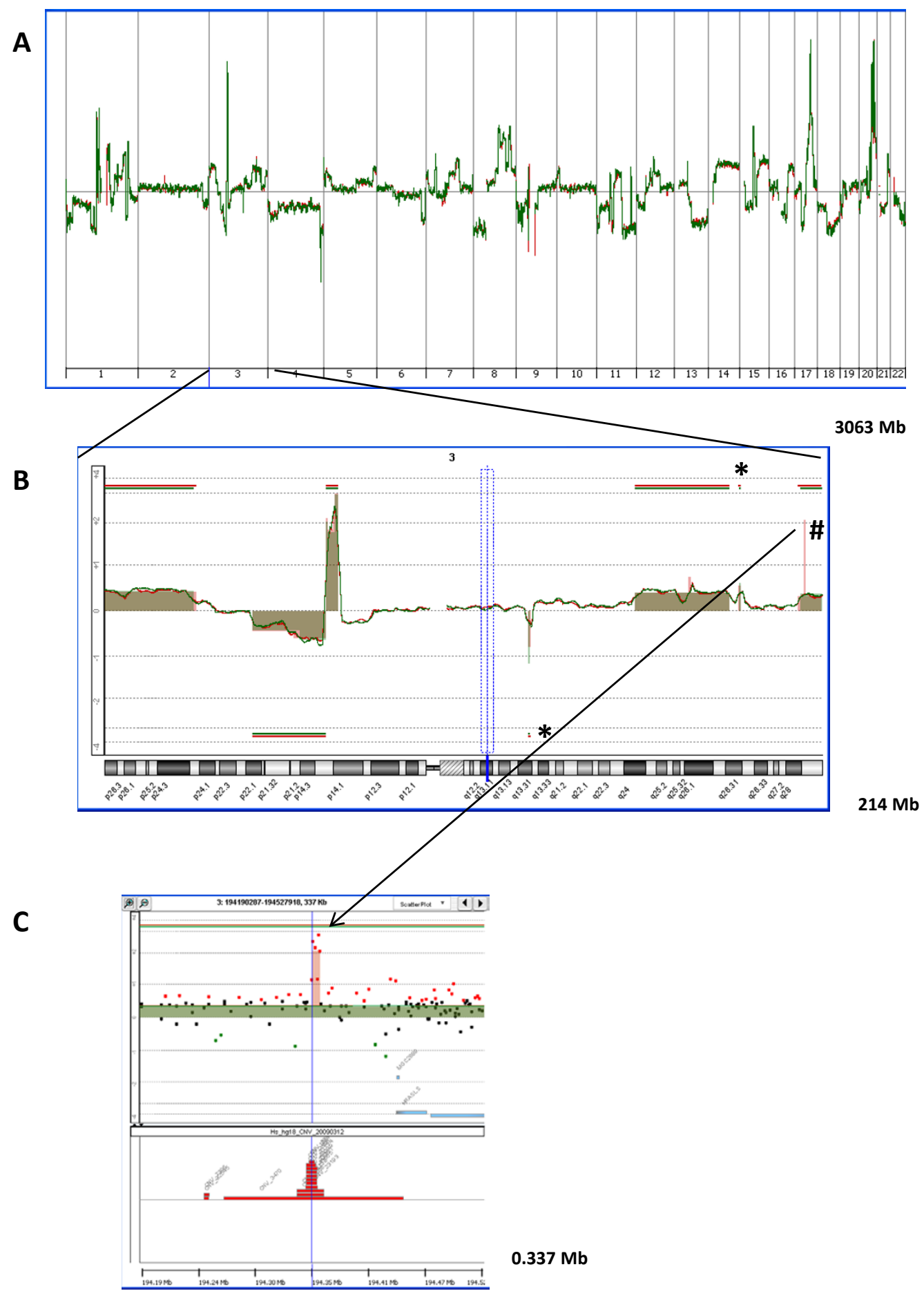

Figure 1 Copy number alterations (CNAs) found in a genome of MCF-7 cells with ultra-dense array CGH platforms. Genomic DNA from MCF-7 cells was hybridized to slides containing either $244 \mathrm{~K}$ oligonucleotide probes (green) or $1 \mathrm{M}$ oligonucleotide probes (red). (A) The whole genome view of overlaid moving averages ( $2 \mathrm{Mb}$ window) for $\log _{2}$ ratios of fluorescence between labeled MCF-7 DNA and the differentially labeled normal human reference. (B) Zoom-in on chromosome 3 showing overlaid moving averages and aberrations found with the ADM-2 algorithm. Aberrations smaller than $1 \mathrm{Mb}$ in genomic length are indicated; those found with both $244 \mathrm{~K}$ and $1 \mathrm{M}$ platforms $\left(^{*}\right)$ and those found with the $1 \mathrm{M}$ platform only (\#). (C) Zoom-in on the smallest aberration, $8 \mathrm{~Kb}$ amplification, found only with the $1 \mathrm{M}$ platform. Overlaid data points for $\log _{2}$ ratios obtained with $1 \mathrm{M}$ platform and $244 \mathrm{~K}$ platform are shown (green: values below $\log _{2}=-0.5$; red: values above log $2=0.5$; black: values above $\log _{2}=-0.5$ and below $\log _{2}=0.5$ ). Aberrations called by the ADM-2 algorithm are identified by a shaded area, and the presence of CNVs is indicated with red boxes (bottom). 
Table 1 All CNAs smaller than $1 \mathrm{Mb}$, identified with both ultra-dense platforms

\begin{tabular}{|c|c|c|c|c|c|c|c|c|}
\hline \# & Chromosome & $\begin{array}{l}\text { Start position of CNA } \\
\text { found only with } 1 \mathrm{M} \\
\text { platform }\end{array}$ & $\begin{array}{l}\text { Start position of CNA } \\
\text { found with both } \\
\text { platforms }\end{array}$ & $\begin{array}{l}\text { Amplification } \\
\text { (A) or Deletion } \\
\text { (D) }\end{array}$ & $\begin{array}{l}\text { Length } \\
\text { of CNA }\end{array}$ & $\begin{array}{l}\text { Presence } \\
\text { of known } \\
\text { CNV }\end{array}$ & $\begin{array}{l}\text { Number of } \\
\text { genes } \\
\text { involved }\end{array}$ & $\begin{array}{l}\text { Names of } \\
\text { genes } \\
\text { involved }\end{array}$ \\
\hline 1 & 3 & $194,358,885$ & & $A$ & 8,065 & CNV & 0 & \\
\hline 2 & 1 & $150,841,957$ & & D & 9,482 & CNV & 0 & \\
\hline 3 & 7 & $109,230,336$ & & $D$ & 9,874 & CNV & 0 & \\
\hline 4 & 7 & $141,698,634$ & & D & 15,534 & CNV & 0 & \\
\hline 5 & 17 & $4,986,617$ & & A & 20,455 & & 1 & USP6 \\
\hline 6 & 17 & $59,743,208$ & & A & 31,300 & & 1 & PECAM 1 \\
\hline 7 & 1 & $72,539,143$ & & A & 40,168 & CNV & 0 & \\
\hline 8 & 18 & & $3.210,260$ & A & 64,250 & & 3 & $\begin{array}{l}\text { MYOM1 } \\
\text { MYL12A } \\
\text { MYL12B }\end{array}$ \\
\hline 9 & 6 & $79,024,557$ & & D & 67,293 & CNV & 0 & \\
\hline 10 & 12 & $38,617,085$ & & D & 68,417 & & $1^{*}$ & $S L C 2 A 13$ \\
\hline 11 & 12 & $9,528,590$ & & D & 81,464 & CNV & 0 & \\
\hline 12 & 12 & $38,437,305$ & & $A$ & 91,984 & & $1^{*}$ & SLC2A13 \\
\hline 13 & 15 & & $32,482,458$ & D & 96,025 & CNV & 1 & GOLGA8A \\
\hline 14 & 5 & & $59,959,592$ & A & 133,110 & & 2 & $\begin{array}{l}\text { DEPDC1B } \\
\text { ELOVL7 }\end{array}$ \\
\hline 15 & 17 & & $78,519,743$ & A & 133,802 & & 2 & $\begin{array}{l}\text { B3GNTL1 } \\
\text { METRNL }\end{array}$ \\
\hline 16 & 20 & & $48,722,374$ & A & 133,933 & CNV & 2 & $\begin{array}{l}\text { BCAS4 } \\
\text { PARD6B }\end{array}$ \\
\hline 17 & 8 & & $39,356,595$ & A & 148,661 & CNV & 2 & $\begin{array}{l}\text { ADAM5P } \\
\text { ADAM3A }\end{array}$ \\
\hline 18 & 14 & & $37,104,288$ & A & 149,393 & & 1 & FOXA1 \\
\hline 19 & 20 & & $3,656,779$ & A & 159,562 & & 7 & $\begin{array}{l}\text { C20orf27 } \\
\text { MAVS } \\
\text { C20orf29 } \\
\text { CDC25B } \\
\text { CENPB } \\
\text { SPEF1 } \\
\text { HSPA12B }\end{array}$ \\
\hline 20 & 20 & & $55,111,937$ & A & 175,024 & & 1 & BMP7 \\
\hline 21 & 4 & $91,703,176$ & & D & 178,258 & & 1 & FAM190A \\
\hline 22 & 6 & & $151,895,709$ & $A$ & 190,191 & & 2 & $\begin{array}{l}\text { C6orf97 } \\
\text { ESR1 }\end{array}$ \\
\hline 23 & 1 & & $112,169,367$ & A & 202,264 & & 1 & KCND3 \\
\hline 24 & 9 & $21,842,925$ & & D & 221,323 & CNV & 4 & $\begin{array}{l}\text { MTAP } \\
\text { CDKN2A } \\
\text { CDKN2B } \\
\text { CDKN2BAS }\end{array}$ \\
\hline 25 & 20 & & $14,879,882$ & $\mathrm{D}$ & 229,686 & & 1 & MACROD2 \\
\hline 26 & 1 & & $200,010,125$ & $D$ & 242,671 & & 7 & $\begin{array}{l}\text { NAV1 } \\
\text { IPO9 } \\
\text { SHISA4 } \\
\text { LMOD1 } \\
\text { TIMM17A } \\
\text { RNPEP } \\
\text { ELF3 }\end{array}$ \\
\hline 27 & 1 & & $120,065,684$ & A & 349,836 & CNV & 6 & $\begin{array}{l}\text { PHGDH } \\
\text { HMGCS2 } \\
\text { REG4 } \\
\text { NBPF7 } \\
\text { ADAM30 } \\
\text { NOTCH2 }\end{array}$ \\
\hline
\end{tabular}


Table 1 All CNAs smaller than $1 \mathrm{Mb}$, identified with both ultra-dense platforms (Continued)

\begin{tabular}{|c|c|c|c|c|c|c|c|c|}
\hline 28 & 17 & & $56,240,772$ & A & 384,084 & & 1 & BCAS3 \\
\hline 29 & 7 & & $64,328,811$ & D & 393,567 & CNV & 3 & $\begin{array}{l}\text { ZNF92 } \\
\text { INTS4L1 } \\
\text { INTS4L2 }\end{array}$ \\
\hline 30 & 4 & & $182,164,553$ & D & 410,882 & & 0 & \\
\hline 31 & 7 & & $157,963,956$ & A & 413,345 & & 4 & $\begin{array}{l}\text { PTPRN2 } \\
\text { NCAPG2 } \\
\text { FAM62B } \\
\text { WDR60 }\end{array}$ \\
\hline 32 & 1 & $147,203,277$ & & D & 441,554 & CNV & 3 & $\begin{array}{l}\text { LOC645166 } \\
\text { LOC388692 } \\
\text { FCGR1C }\end{array}$ \\
\hline 33 & 17 & & $70,788,571$ & A & 541,784 & CNV & 14 & $\begin{array}{l}\text { SLC25A19 } \\
\text { GRB2 } \\
\text { KIAA0195 } \\
\text { CASKIN2 } \\
\text { TSEN54 } \\
\text { LLGL2 } \\
\text { RECQL5 } \\
\text { SAP30BP } \\
\text { ITGB4 } \\
\text { GALK1 } \\
\text { H3F3B } \\
\text { UNK } \\
\text { MYO15B } \\
\text { LOC643008 }\end{array}$ \\
\hline 34 & 9 & & 637,589 & A & 558,789 & & 4 & $\begin{array}{l}\text { KANK1 } \\
\text { DMRT1 } \\
\text { DMRT3 } \\
\text { DMRT2 }\end{array}$ \\
\hline 35 & 17 & & $42,299,184$ & A & 602,830 & & 8 & $\begin{array}{l}\text { WNT9B } \\
\text { GOSR2 } \\
\text { RPRML } \\
\text { CDC27 } \\
\text { MYL4 } \\
\text { ITGB3 } \\
\text { C17orf57 } \\
\text { LOC100272146 }\end{array}$ \\
\hline 36 & 3 & & $176,160,173$ & A & 678,671 & & 1 & NAALADL2 \\
\hline 37 & 3 & & $117,722,695$ & D & 680,165 & & 1 & LOC285194 \\
\hline 38 & 1 & $107,928,934$ & & A & 910,775 & & 4 & $\begin{array}{l}\text { VAV3 } \\
\text { SLC25A24 } \\
\text { NBPF4 } \\
\text { NBPF6 }\end{array}$ \\
\hline 39 & 12 & & $32,954,990$ & A & 988,660 & & 1 & SYT10 \\
\hline
\end{tabular}

platform, 9 micro-CNAs were localized to sites of common copy number variations (CNVs) as per the Toronto CNV database integrated in the Agilent Genomic Workbench and 7 of these contained no genes (Table 1 ). Three of these measured less than $10 \mathrm{~Kb}$ in genomic length. Since the normal counterpart for MCF-7 cells is not available, it is not possible to determine if these CNVs are truly somatic in this case.

Fourteen of the 39 (36\%) micro-CNAs involved only a single gene (Figure 2A), including 7 DNA copy gains and 7 DNA copy losses. Five of the 15 micro-CNAs detected only by the $1 \mathrm{M}$ arrays involved one gene each and 3 larger regions involved 3-4 genes each. The five single gene micro-CNAs detected only by $1 \mathrm{M}$ arrays were 3 DNA copy gains and 2 DNA copy losses. One gene (SLC2A13) was affected twice, i.e. by a DNA copy gain and a DNA copy loss involving different segments of the gene (Figure $2 \mathrm{~B}$ ), and the 3 other affected genes were: USP6 (gain) (Figure 2C), PECAM1 (gain), FAM190A (loss).

Interestingly, a DNA copy number loss of a small fragment of chromosome 9 next to the CDKN2A (p16) gene observed in the $244 \mathrm{~K}$ arrays was better mapped in the $1 \mathrm{M}$ arrays, and was found to include the CDKN2A (p16) gene as well as the neighboring MTAP gene (Figure 2D). The MTAP gene has been reported to be a 
A

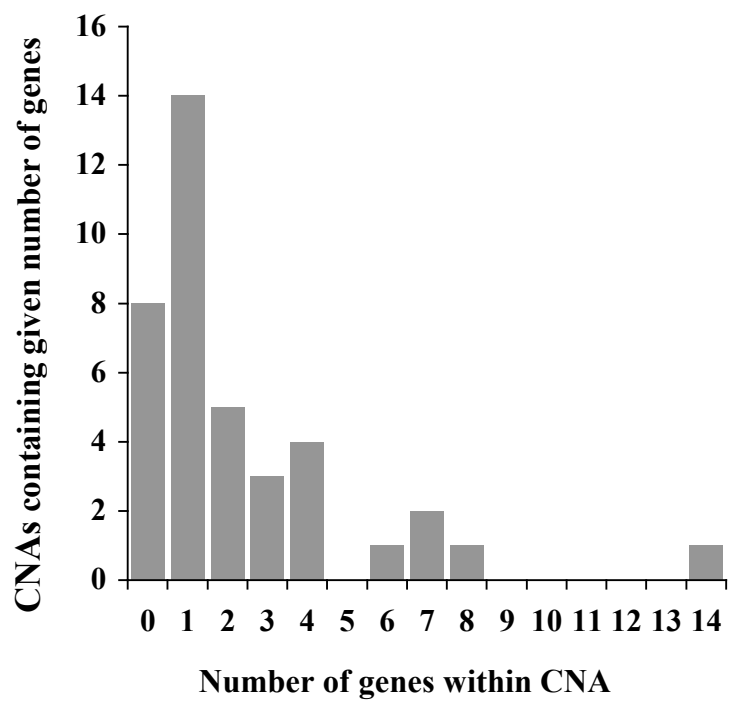

C

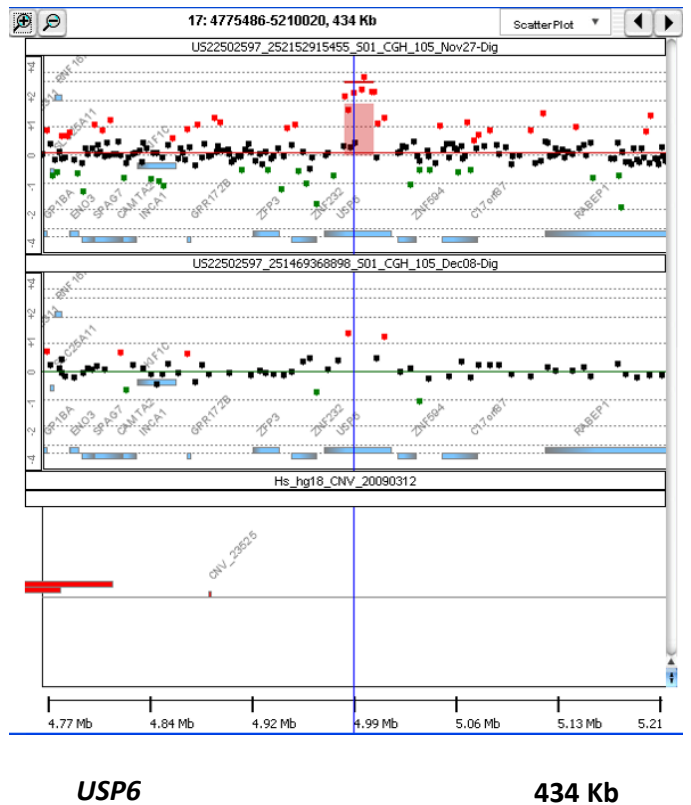

B

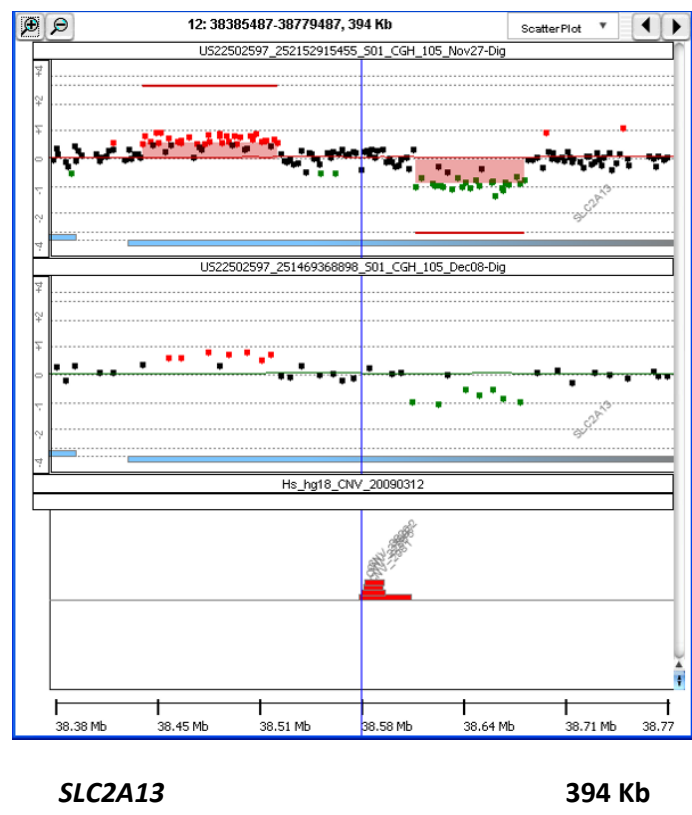

D

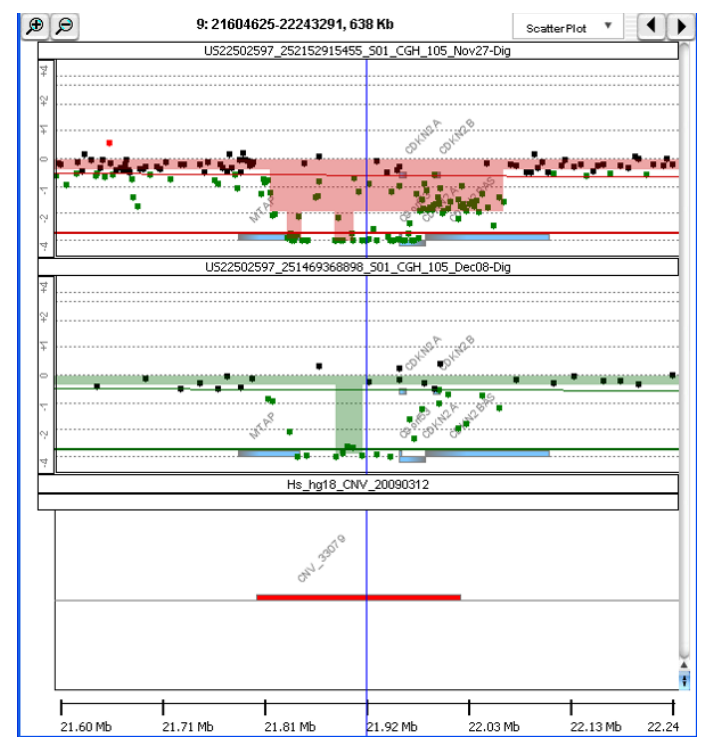

MTAP

$638 \mathrm{~Kb}$

CDKN2A

CDKN2B

CDKN2BAS

Figure 2 Micro-CNAs smaller than 1 Mb in genomic length. (A) Distribution of number of genes within micro-CNAs discovered with both $244 \mathrm{k}$ and $1 \mathrm{M}$ arrays. (B, C and D) Examples of micro-CNAs found only with $1 \mathrm{M}$ platform. Panels show DNA copy number data points and moving averages for the $1 \mathrm{M}$ platform (top, shown in red) or $244 \mathrm{~K}$ platform (middle, shown in green). Aberrations are identified by shaded blocks, genes by shaded blue boxes, and the presence of CNVs is indicated with red boxes (bottom). (B) Amplification and deletion within SLC2A13 gene. (C) Amplification of USP6 gene. (D) Deletion of MTAP gene. 
candidate tumor suppressor gene $[15,16]$. To our knowledge we are the first to report copy number losses of MTAP and CDKN2A in this cell line and to associate a $\mathrm{CNV}$ to this DNA site.

In all, 84 named genes were involved in micro-CNAs (Table 1). We performed a gene ontology search for common biologic processes affected by these genes using the publicly accessible DAVID bioinformatics resources http://david.abcc.ncifcrf.gov, version 6.7. The biologic process category of "cell cycle" was the only gene ontology term enriched with a $p$ value $<0.01$ in this gene set $(p=0.0055)$. This category included 9 genes: NOTCH2, PARD6B, CDKN2A, CDKN2B, NCAPG2, PHGDH, CDC27, CDC25B, LLGL2. Of note, five genes involved in micro-CNAs were associated with estrogen receptor (ER) signaling: FOXA1, BMP7, ESR1 $V A V 3$ and $P A R D 6 B$ [17-20]. Interestingly, FOXA1 is a candidate biomarker of poor prognosis in breast tumors [17], $B M P 7$ is a biomarker of bone metastasis in breast cancer [21] and VAV3 is an oncogene, which maps to a $910 \mathrm{~Kb}$ amplified region and is known to be overexpressed in MCF-7 cells [19]. Taken together, our findings suggest that ultra-high resolution array $\mathrm{CGH}$, especially the $1 \mathrm{M}$ Agilent platform, leads to the detection of micro-CNAs involving both CNVs and genes with a high degree of sensitivity.

\section{The detection of breakpoints of chromosomal rearrangements by array CGH}

The formation of chromosomal rearrangements such as translocations as well as genomic deletions and amplifications involves double strand DNA breaks [22]. In our data, several genes involved in micro-CNAs ( 9 genes or $10 \%$ of all involved genes) mapped to CNAs in close proximity of known break points or hot spots in chromosomes. Those CNAs were either DNA copy number gains (USP6, NAALADL2, BCAS4, DEPDC1B/ELOVL7, $B C A S 3$ ) (Figure 2C, 3A and 3B) or losses (FAM190A, $M A C R O D 2, M T A P)$ (Figure 2D) [23-31]. Moreover, using the $1 \mathrm{M}$ array CGH platform, we observed several sites of apparent intra-genic alterations in DNA copy number, suggestive of DNA breakage within genes. We hypothesize that such intra-genic DNA breaks may in some cases indicate gene fusion events. Indeed, recent evidence suggests that such fusion events are more common than previously thought [32]. Hampton et al. recently published a list of gene fusions that involve splicing sites of intact coding exons discovered in the MCF-7 cell line using a parallel sequencing approach [28]. Sixteen distinct genes are involved in these gene fusions in MCF-7 cells, in 4 intra-chromosomal events ( 1 translocation and 3 inversions) and 6 inter-chromosomal rearrangements, mapping to 6 different chromosomal areas in total (Table 2). Fourteen of these sixteen genes are contained in chromosomal segments affected by DNA copy number gains in the MCF-7 cell line. In our array $\mathrm{CGH}$ data, we found that 10 of these 16 genes (Table 2) contained intra-genic copy number alterations, mostly complex changes in DNA copy number. Four of these genes (DEPDC1B, ELOVL7, BCAS3 and BCAS4) involved regions of micro-copy number alterations that we identified and listed in Table 1 (Figure 3A and 3B), while the others involved larger chromosomal rearrangements. The one intra-chromosomal translocation involving the DEPDC1B and ELOVL7 genes was detected as an increase in DNA copy number involving both adjacent genes, but breaking each of them within the gene (Figure 3A). Interestingly, three of the 16 genes (ARFGEF2, SULF2 and PRKCBP1) were contained in one large segment of chromosome 20 affected by DNA copy number gain and two others (PTPRG and ATXN7) in a large segment of chromosome 3 adjacent to the $F R A 3 B$ fragile site (Figure $3 C$ ). Thanks to the ultra-dense spacing of probes on the arrays we were able to break down such large chromosomal segments into smaller regions which differ in copy number values and most likely reflect complex sequence rearrangements (Figure $3 \mathrm{~B}$ and $3 \mathrm{C}$ ). These findings suggest that array $\mathrm{CGH}$ can also detect chromosomal breaks and rearrangements, which are often accompanied by DNA copy number gains or amplifications. Moreover, ultra-dense array CGH may become a tool to identify gene fusion events similar to what was already suggested for high-resolution single nucleotide polymorphism genomic microarray (SNP-Chip) [33].

\section{Ultra-dense array CGH analysis reveals micro- amplifications and micro-deletions, which are artifacts inherent to the whole genome amplification}

To determine the effect of whole genome amplification (WGA) on the detection of micro-CNAs using the ultra-high density platforms, we compared array $\mathrm{CGH}$ results from amplified DNA to non-amplified DNA from the MCF-7 cell line, using both the $1 \mathrm{M}$ and 244 $\mathrm{K}$ arrays. The array CGH data obtained with $244 \mathrm{~K}$ and $1 \mathrm{M}$ arrays (Figure 4C and 4D) was remarkably reproducible at the genome and chromosomal levels regardless if DNA was amplified or not. However, further magnification to the sub-chromosomal level revealed many repetitive, periodic artifacts in amplified samples (Figure $4 \mathrm{~A}$ and $4 \mathrm{~B}$ ). This "wave" effect was manifested as the more or less regular periodic appearance of discrete decreases in DNA copy number values spanning about 10-100 Kb, and occurring approximately every 50-500 $\mathrm{Kb}$ along each chromosome, with an amplitude of approximately $1-1.5 \log _{2}$ ratio values. These $\log _{2}$ ratio value dips were observed in all genomic regions including those of altered copy number (Figure $4 \mathrm{~A}$ and $4 \mathrm{~B}$ ). 
A

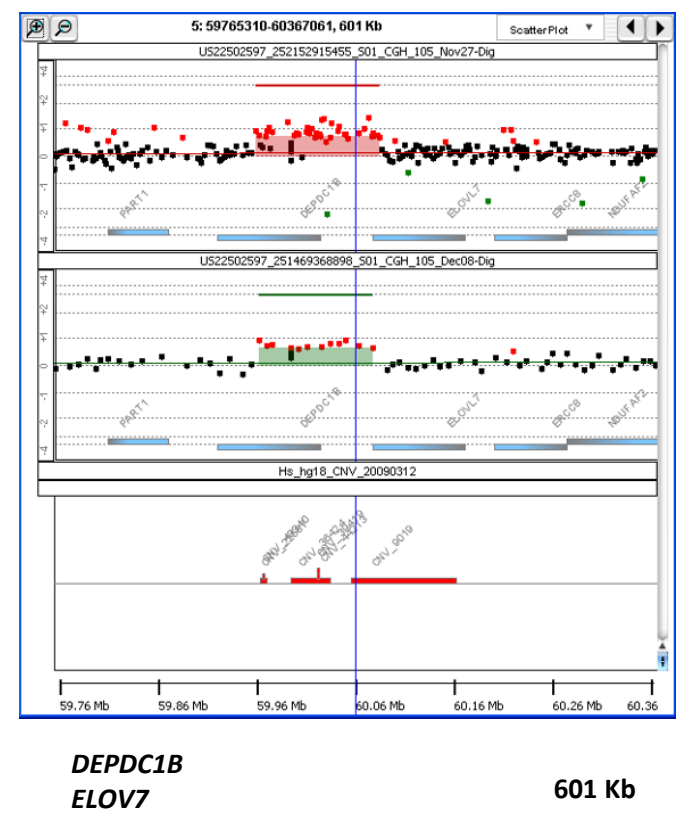

C

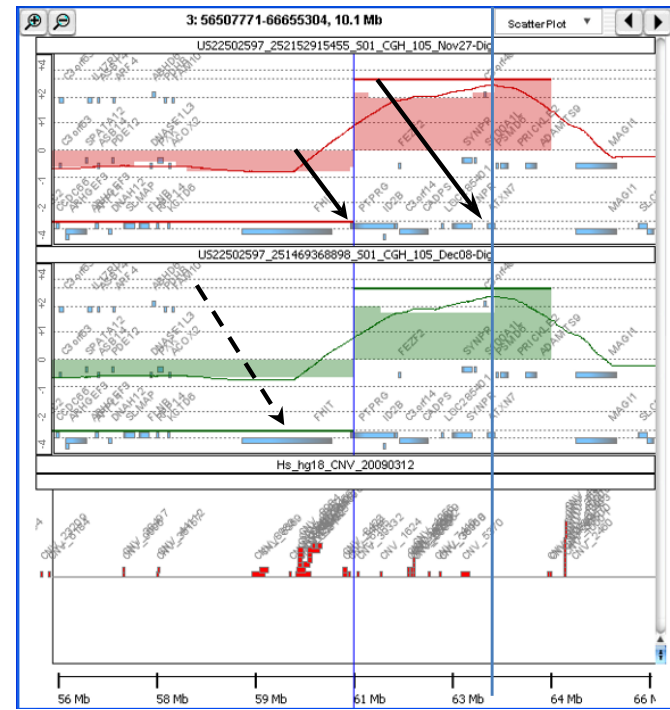

PTPRG

ATXN7
B

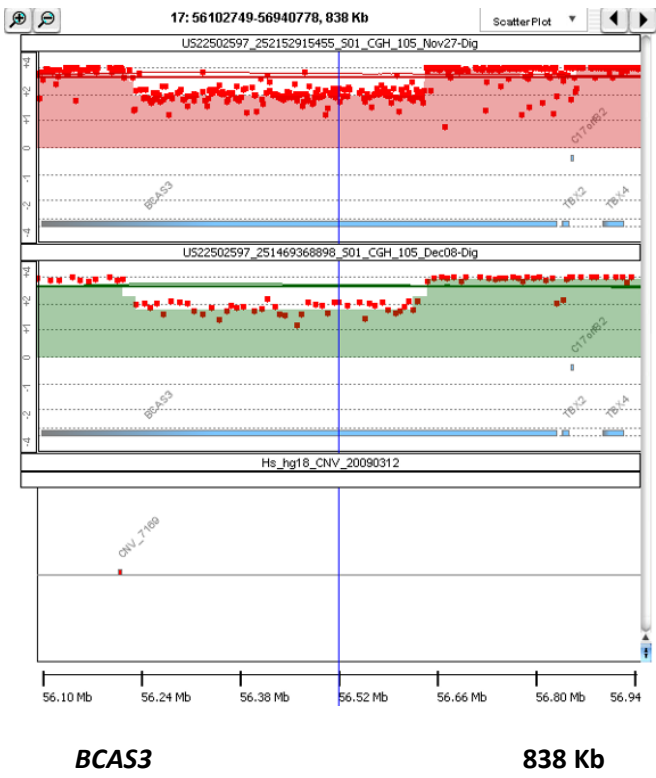

D 
Table 2 Genes involved in chromosomal rearrangements in MCF-7 cells, as identified by Hampton et al

\begin{tabular}{|c|c|c|c|}
\hline Genes & Type of rearrangement & $\begin{array}{c}\text { Intra-genic break (detected by array } \\
\text { CGH) }\end{array}$ & $\begin{array}{l}\text { Copy number alteration (detected by array } \\
\text { CGH) }\end{array}$ \\
\hline ARFGEF2 & intrachromosomal inversion & yes & Amplification \\
\hline ASTN2 & interchromosomal & no & \\
\hline ATXN7 & interchromosomal & yes & Amplification \\
\hline BCAS4 & $\begin{array}{c}\text { interchromosomal and intrachromosomal } \\
\text { inversion }\end{array}$ & yes & Amplification \\
\hline BCAS3 & interchromosomal & yes & Amplification \\
\hline DEPDC1B & intrachromosomal translocation & yes & Amplification \\
\hline ELOVL7 & intrachromosomal translocation & yes & Amplification \\
\hline NPEPPS & intrachromosomal inversion & no & Amplification \\
\hline PRICKLE2 & interchromosomal & no & Amplification \\
\hline PRKCBP1 & intrachromosomal inversion & no & Amplification \\
\hline PTPRG & interchromosomal & yes & Amplification \\
\hline RAD51C & interchromosomal & no & Amplification \\
\hline RSBN1 & interchromosomal & yes & Amplification \\
\hline SULF2 & interchromosomal & yes & Amplification \\
\hline TBC1D16 & interchromosomal & no & \\
\hline USP32 & intrachromosomal inversion & yes & Amplification \\
\hline
\end{tabular}

This phenomenon considerably confounded the calling of aberrations by the ADM-2 algorithm. We repeated WGA in 3 separate experiments and found that the number of aberrations called by the ADM- 2 algorithm in the entire genome varied from 125 in experiment \#1 to 561 in experiment \#2 and 778 in experiment \#3. Since only 39 of those aberrations were found when non-amplified DNA was used for analysis, most of these apparent CNAs are in fact artifacts of DNA amplification. Thus, the number of artifacts greatly exceeded the number of true aberrations. In experiment \#1, with the smallest number of artifacts, the majority of them appeared as DNA copy number losses (68.8\%). We also found that only $21 \%$ of "false" aberrations were found in all three experiments, suggesting that most DNA copy number artifacts are produced randomly during the WGA process. These "wave" artifacts are easily detectable visually in amplified samples analyzed with $1 \mathrm{M}$ platform. Thus, they are not associated specifically with the ADM-2 algorithm. In contrast with the $1 \mathrm{M}$ platform, the use of the 244 $\mathrm{K}$ array CGH platform after WGA did not result in such a dramatic number of artifacts. Indeed, the "wave" effect was hardly visible with this platform (Figure 4E and 4F). In three independent experiments performed with amplified DNA the number of aberrations varied from 38 in experiment $\# 1$ to 36 in experiment \#2 and 35 in experiment \#3, compared to a total of 24 micro-CNAs when non-amplified DNA was used for analysis. Thus, the number of potential artifacts was small relative to that found with the denser $1 \mathrm{M}$ platform. In addition, $71 \%$ of those artefactual CNAs were common to all three replicates, suggesting that the artifacts observed in this platform may be more dependent on sequence context. Thus, the ultra-dense array $\mathrm{CGH}$ platforms, especially the densest $1 \mathrm{M}$ arrays, detect artifacts inherent to WGA and should be used only with non-amplified DNA samples to detect micro-CNAs.

\section{Conclusion}

Our goal is to identify novel targets for therapy and molecular biomarkers with greater precision starting from an in-depth analysis of CNAs present in the breast cancer genome. The advent of ultra-high resolution genomic analysis allows the discovery of novel and very small CNAs hitherto undetectable before, which may involve only single genes. In this first report of the use of the ultra-dense $1 \mathrm{M}$ array CGH Agilent platform for the analysis of DNA from cancer cells, we detected previously unknown intra-genic CNAs affecting genes in the MCF-7 breast cancer cell line, some of which are potentially relevant to cancer biology. Indeed we found that the limit of sensitivity of detection of CNAs of the $244 \mathrm{~K}$ array CGH platform is approximately $100 \mathrm{~Kb}$. We have shown that a significant number of smaller micro-CNAs (15 out of total 39,38\%) were only detected by the $1 \mathrm{M}$ array; this includes 9 CNVs as well as two novel amplicons involving the USP6 and the PECAM1 genes. Micro-CNAs that cut through exonic sequences may indicate potential sites of chromosomal rearrangements and translocations. We found that several gene fusions present in the MCF-7 cell line were 
A

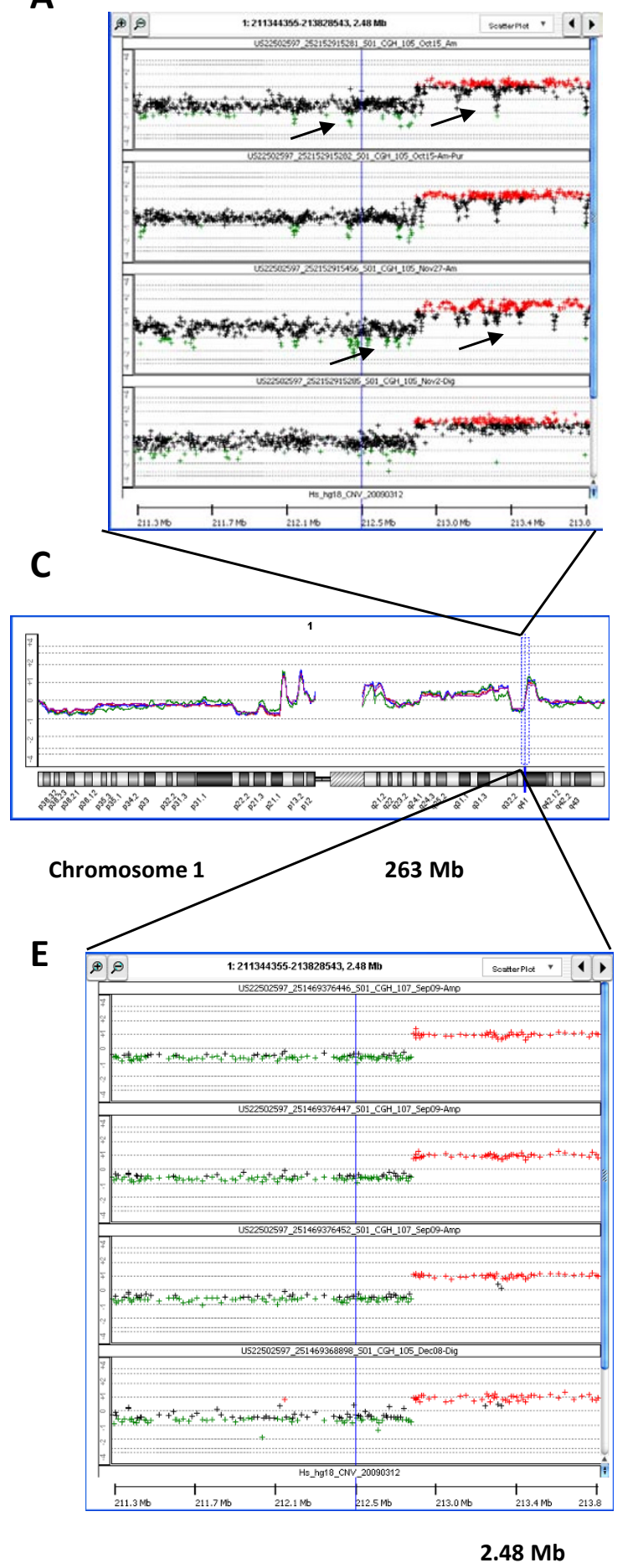

B

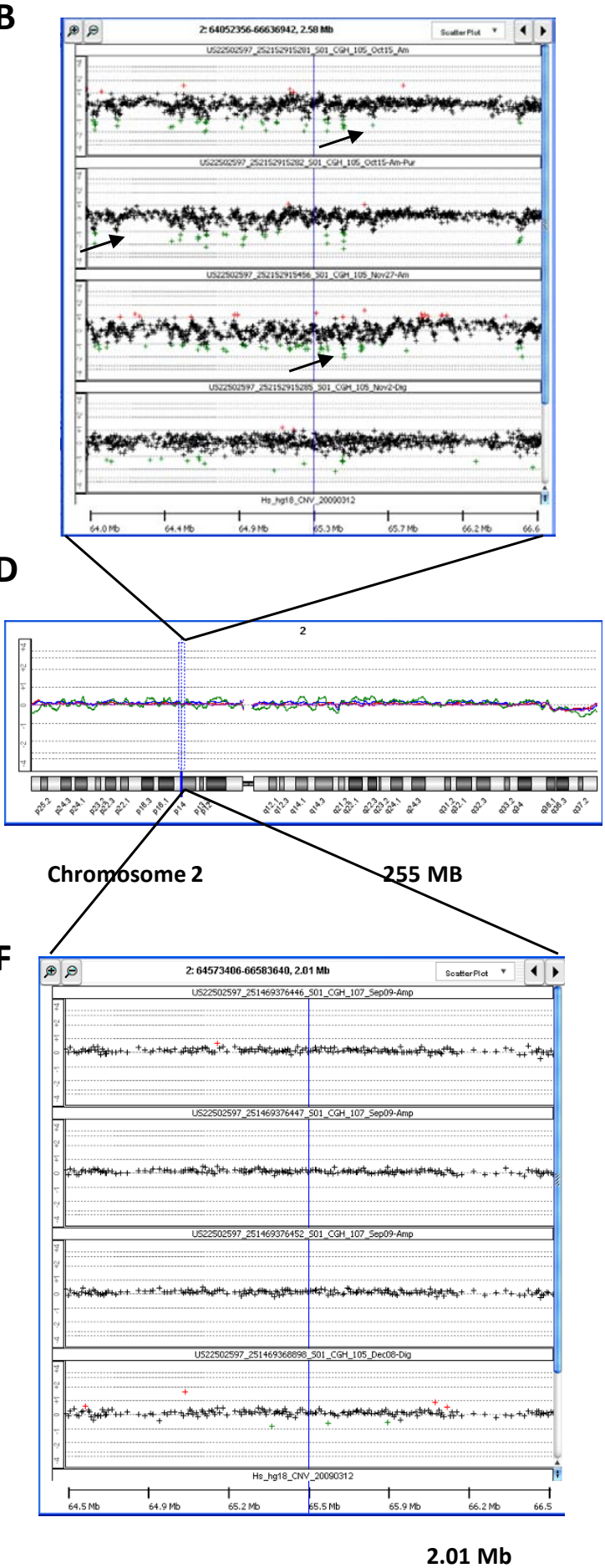

Figure 4 Array CGH using $1 \mathrm{M}$ platform and whole genome amplified DNA reveals artifacts due to whole genome amplification. Array CGH of whole-genome amplified DNA from the MCF-7 cell line compared to non-amplified DNA, with magnification of two small segments in chromosomes 1 and 2. (A, B) Data obtained with $1 \mathrm{M}$ platform. In three independent experiments (top 3 sections) DNA was amplified using the Phi29 polymerase kit. The fourth experiment (bottom section) was performed without WGA. Arrows indicate some of the WGA artifacts. (C, D) Array CGH results from the $1 \mathrm{M}$ platform shown as overlaid moving averages obtained in 4 experiments; 3 with WGA-DNA (blue, green, red) and 1 without amplification (purple). (C) Zoom-out on chromosome 1. (D) Zoom-out on chromosome 2. (E, F) Data obtained with $244 \mathrm{~K}$ platform. In three independent experiments (top 3 sections) DNA was amplified using Phi29 polymerase kit. The fourth experiment (bottom section) was performed without WGA. Note the small "wave" effects are seen only in the $1 \mathrm{M}$ arrays when using WGA. 
also marked by complex intra-genic DNA copy number changes detected by ultra-dense array CGH.

In order to apply these technologies to the kind of small biopsy samples increasingly being collected in modern clinical trials, whole genome amplification is frequently required to obtain sufficient quantities of DNA. Using a commercially available and widely used DNA amplification kit, we found that the higher sensitivity of the $1 \mathrm{M}$ microarray results in the cluttering of the array CGH profile by hundreds of "wave" artifacts. Importantly, these "wave" artifacts do not obscure the detection of true CNAs, even when these are intragenic and less than $1 \mathrm{Mb}$ in length. On the other hand, the appearance of many artefactual CNAs limits the analysis of the data at the sub-chromosomal level and the use of copy number detection algorithms such as ADM-2. In this study we did not perform a comparison between DNA from fresh or frozen cells versus that extracted from paraffin-embedded samples. In our experience, the genetic material extracted from such samples is of poorer quality and very small focal DNA copy number changes are more difficult to detect. However there is no reason to suppose that the WGArelated artifacts would not be apparent in poorer quality DNA.

Overall, we have demonstrated the remarkable capacity of ultra-dense array CGH platforms for discovery of cancer genes and biomarkers, but we have also shown that such powerful technology requires excellent quality of genomic DNA and does not tolerate relatively small imperfections related to the whole genome amplification.

\section{Methods \\ Cell line}

The MCF-7 cell line was cultured in RPMI 1640 (R8758; Sigma, St Louis, MO) supplemented with $10 \%$ fetal bovine serum (Hyclone, Logan, UT). Cells in the exponential phase of growth were harvested and DNA extracted using the QuiAmp DNA extraction kit.

\section{Array CGH}

Copy number alterations (CNA) within the MCF-7 genome relative to the sex-matched normal human DNA (Promega, Madison, WI) were identified by array CGH analysis using microarray slides, which contain 244000 $(244 \mathrm{~K})$ and one million $(1 \times 1 \mathrm{M})$ oligonucleotide probes (Agilent Technologies, Santa Clara, CA, USA).

For sample preparation and hybridization we have followed the protocol developed and described in detail by Agilent. Briefly, genomic DNA was extracted from MCF-7 cells using QIAmp DNA Mini Kit (Qiagen, Mississauga, Ontario, Canada). The integrity of DNA was confirmed with nanodrop and agarose gel electrophoresis. For array CGH without WGA, we used $2.5 \mu \mathrm{g}$ of
MCF-7 DNA and $2.5 \mu \mathrm{g}$ of reference DNA for each analysis. DNA was digested with Rsa I and Alu I and labeled by random priming using either Cy5-dUTP or Cy3-dUTP. Following purification with Microcon Centrifugation Filters, Ultracel YM-30 (Millipore, Billerica, Ma, USA), probes were denatured and pre-annealed with $50 \mu \mathrm{g}$ of human Cot-1 DNA (Invitrogen, Burlington, Ontario, Canada). Hybridization was performed at $65{ }^{\circ} \mathrm{C}$ for $40 \mathrm{~h}$ with constant rotation.

After hybridization, slides were washed according to the manufacturer's instructions and scanned immediately with a DNA Microarray Scanner (Agilent Technologies). Data were extracted from scanned images using Feature Extraction software, version 10.7.3.1 (Agilent). The text files were then imported for analysis into Genomic Workbench, standard edition 5.0.14 (Agilent). We used the Aberration Detection Method 2 (ADM-2) algorithm to identify DNA copy number aberrations. The ADM-2 algorithm identifies all aberrant intervals in a given sample with consistently high or low log ratios based on the statistical score. It then samples adjacent probes to arrive at an estimation of the true range of the aberrant segment. The statistical score represents the deviation of the average of the log ratios from the expected value of zero, in units of standard deviation. The algorithm searches for intervals in which a statistical score based on the average quality weighted log ratio of the sample and reference channels exceeds a user specified threshold. Although a threshold of 6 is recommended in the instruction manual, we used a conservative threshold of 10 because visual inspection of the array plots led to the rejection of several aberrations called using the lower threshold. We applied a filtering option of minimum of 5 probes in region and minimum absolute average $\log _{2}$ ratio $>0.3$. USCS human genome assembly hg18 was used as a reference and copy number variations (CNV) were identified with a database integrated in the Agilent Genomic Workbench analytic software.

\section{Whole genome amplification}

For array CGH with WGA, we used $60 \mathrm{ng}$ of both MCF-7 and reference DNA for each analysis. In this case, whole genomic DNA was amplified using GenomiPhi V2 DNA Amplification Kit (GE Healthcare UK Limited, Buckinghamshire, UK), which uses random primers to target the entire DNA template and $\phi 29$ DNA polymerase. WGA generated 7-10 $\mu \mathrm{g}$ of labeled DNA (MCF-7 and reference DNA) for hybridization. Amplified DNA was labeled and purified exactly the same way as digested, non-amplified DNA.

\section{List of abbreviations}

ADM-2: Aberration detection method 2; Array CGH: array comparative genomic hybridization; CNA: copy number alterations; CNV: copy number 
variations; $1 \mathrm{M}$ array: array $\mathrm{CGH}$ containing one million $(1 \times 1 \mathrm{M})$ oligonucleotide probes; $244 \mathrm{~K}$ array: array CGH containing 244000 oligonucleotide probes; WGA: whole genome amplification.

\section{Acknowledgements and funding}

We acknowledge support from the Weekend to End Breast Cancer/Jewish General Hospital Foundation, the CIHR funded McGill Integrated Research Training Program (support to E.P.), the National Cancer Institute of Canada (support to C.F.) and the Quebec Breast Cancer Foundation.

\section{Competing interests}

The authors declare that they have no competing interests.

\section{Authors' contributions}

EP: designed the study, carried out all the experiments, performed data analysis, data interpretation and drafted the manuscript; CF: participated in data interpretation and in preparation of the manuscript; MB: conceived the study and participated in its design, data analysis and interpretation and helped to draft the manuscript. All authors read and approved the final manuscript.

Received: 5 October 2010 Accepted: 27 January 2011

Published: 27 January 2011

\section{References}

1. Gonzalez E, Kulkarni H, Bolivar H, Mangano A, Sanchez R, Catano G, Nibbs RJ, Freedman Bl, Quinones MP, Bamshad MJ, Murthy KK, Rovin BH, Bradley W, Clark RA, Anderson SA, O'Connell R J, Agan BK, Ahuja SS, Bologna R, Sen L, Dolan MJ, Ahuja SK: The influence of CCL3L1 genecontaining segmental duplications on HIV-1/AIDS susceptibility. Science 2005, 307(5714):1434-1440.

2. Aitman TJ, Dong R, Vyse TJ, Norsworthy PJ, Johnson MD, Smith J, Mangion J, Roberton-Lowe C, Marshall AJ, Petretto E, Hodges MD, Bhangal G, Patel SG, Sheehan-Rooney K, Duda M, Cook PR, Evans DJ, Domin J, Flint J, Boyle JJ, Pusey CD, Cook HT: Copy number polymorphism in Fcgr3 predisposes to glomerulonephritis in rats and humans. Nature 2006, 439(7078):851-855

3. Pinto D, Pagnamenta AT, Klei L, Anney R, Merico D, Regan R, Conroy J, Magalhaes TR, Correia C, Abrahams BS, Almeida J, Bacchelli E, Bader GD, Bailey AJ, Baird G, Battaglia A, Berney T, Bolshakova N, Bolte S, Bolton PF, Bourgeron T, Brennan S, Brian J, Bryson SE, Carson AR, Casallo G, Casey J, Chung $\mathrm{BH}$, Cochrane L, Corsello C, et al: Functional impact of global rare copy number variation in autism spectrum disorders. Nature 2010, 466(7304):368-372.

4. Sebat J, Lakshmi B, Malhotra D, Troge J, Lese-Martin C, Walsh T, Yamrom B, Yoon S, Krasnitz A, Kendall J, Leotta A, Pai D, Zhang R, Lee YH, Hicks J, Spence SJ, Lee AT, Puura K, Lehtimaki T, Ledbetter D, Gregersen PK, Bregman J, Sutcliffe JS, Jobanputra V, Chung W, Warburton D, King MC, Skuse D, Geschwind DH, Gilliam TC, et al: Strong association of de novo copy number mutations with autism. Science 2007, 316(5823):445-449.

5. Ross JS, Fletcher JA, Bloom KJ, Linette GP, Stec J, Symmans WF, Pusztai L, Hortobagyi GN: Targeted therapy in breast cancer: the HER-2/neu gene and protein. Mol Cell Proteomics 2004, 3(4):379-398.

6. Shigematsu H, Gazdar AF: Somatic mutations of epidermal growth factor receptor signaling pathway in lung cancers. Int J Cancer 2006, 118(2):257-262.

7. Mano H: Non-solid oncogenes in solid tumors: EML4-ALK fusion genes in lung cancer. Cancer Sci 2008, 99(12):2349-2355.

8. Neal JW, Sequist LV: Exciting new targets in lung cancer therapy: ALK, IGF-1R, HDAC, and Hh. Curr Treat Options Oncol 2010, 11(1-2):36-44.

9. Shah SP, Morin RD, Khattra J, Prentice L, Pugh T, Burleigh A, Delaney A, Gelmon K, Guliany R, Senz J, Steidl C, Holt RA, Jones S, Sun M, Leung G, Moore R, Severson T, Taylor GA, Teschendorff AE, Tse K, Turashvili G, Varhol R, Warren RL, Watson P, Zhao Y, Caldas C, Huntsman D, Hirst M, Marra MA, Aparicio S: Mutational evolution in a lobular breast tumour profiled at single nucleotide resolution. Nature 2009, 461(7265):809-813.

10. Curtis C, Lynch AG, Dunning MJ, Spiteri I, Marioni JC, Hadfield J, Chin SF, Brenton JD, Tavare S, Caldas C: The pitfalls of platform comparison: DNA copy number array technologies assessed. BMC Genomics 2009, 10:588.

11. Barrett MT, Scheffer A, Ben-Dor A, Sampas N, Lipson D, Kincaid R, Tsang P, Curry B, Baird K, Meltzer PS, Yakhini Z, Bruhn L, Laderman S: Comparative genomic hybridization using oligonucleotide microarrays and total genomic DNA. Proc Natl Acad Sci USA 2004, 101(51):17765-17770.

12. Hughes S, Lim G, Beheshti B, Bayani J, Marrano P, Huang A, Squire JA: Use of whole genome amplification and comparative genomic hybridisation to detect chromosomal copy number alterations in cell line material and tumour tissue. Cytogenet Genome Res 2004, 105(1):18-24.

13. Lovmar L, Syvanen AC: Multiple displacement amplification to create a long-lasting source of DNA for genetic studies. Hum Mutat 2006, 27(7):603-614.

14. Lasken RS: Genomic DNA amplification by the multiple displacement amplification (MDA) method. Biochem Soc Trans 2009, 37(Pt 2):450-453.

15. Lubin $M$, Lubin A: Selective killing of tumors deficient in methylthioadenosine phosphorylase: a novel strategy. PLOS One 2009, 4(5):e5735.

16. Christopher SA, Diegelman P, Porter CW, Kruger WD: Methylthioadenosine phosphorylase, a gene frequently codeleted with p16(cdkN2a/ARF), acts as a tumor suppressor in a breast cancer cell line. Cancer Res 2002, 62(22):6639-6644.

17. Albergaria A, Paredes J, Sousa B, Milanezi F, Carneiro V, Bastos J, Costa S, Vieira D, Lopes N, Lam EW, Lunet N, Schmitt F: Expression of FOXA1 and GATA-3 in breast cancer: the prognostic significance in hormone receptor-negative tumours. Breast Cancer Res 2009, 11(3):R40.

18. Kusumegi T, Tanaka J, Kawano M, Yonemoto J, Tohyama C, Sone H: BMP7/ ActRIIB regulates estrogen-dependent apoptosis: new biomarkers for environmental estrogens. J Biochem Mol Toxicol 2004, 18(1):1-11.

19. Lee K, Liu Y, Mo JQ, Zhang J, Dong Z, Lu S: Vav3 oncogene activates estrogen receptor and its overexpression may be involved in human breast cancer. BMC Cancer 2008, 8:158.

20. Labhart P, Karmakar S, Salicru EM, Egan BS, Alexiadis V, O'Malley BW Smith CL: Identification of target genes in breast cancer cells directly regulated by the SRC-3/AIB1 coactivator. Proc Natl Acad Sci USA 2005, 102(5):1339-1344.

21. Alarmo EL, Korhonen T, Kuukasjarvi T, Huhtala H, Holli K, Kallioniemi A: Bone morphogenetic protein 7 expression associates with bone metastasis in breast carcinomas. Ann Oncol 2008, 19(2):308-314.

22. Tanaka H, Yao MC: Palindromic gene amplification-an evolutionarily conserved role for DNA inverted repeats in the genome. Nat Rev Cancer 2009, 9(3):216-224.

23. Ou Z, Jarmuz M, Sparagana SP, Michaud J, Decarie JC, Yatsenko SA, Nowakowska B, Furman P, Shaw CA, Shaffer LG, Lupski JR, Chinault AC, Cheung SW, Stankiewicz P: Evidence for involvement of TRE-2 (USP6) oncogene, low-copy repeat and acrocentric heterochromatin in two families with chromosomal translocations. Hum Genet 2006, 120(2):227-237.

24. Oliveira AM, Perez-Atayde AR, Dal Cin P, Gebhardt MC, Chen CJ, Neff JR, Demetri GD, Rosenberg AE, Bridge JA, Fletcher JA: Aneurysmal bone cyst variant translocations upregulate USP6 transcription by promoter swapping with the ZNF9, COL1A1, TRAP150, and OMD genes. Oncogene 2005, 24(21):3419-3426.

25. Borg K, Stankiewicz P, Bocian E, Kruczek A, Obersztyn E, Lupski JR, Mazurczak T: Molecular analysis of a constitutional complex genome rearrangement with 11 breakpoints involving chromosomes 3, 11, 12, and 21 and a approximately $0.5-\mathrm{Mb}$ submicroscopic deletion in a patient with mild mental retardation. Hum Genet 2005, 118(2):267-275.

26. Ruan Y, Ooi HS, Choo SW, Chiu KP, Zhao XD, Srinivasan KG, Yao F, Choo CY, Liu J, Ariyaratne P, Bin WG, Kuznetsov VA, Shahab A, Sung WK, Bourque G, Palanisamy N, Wei CL: Fusion transcripts and transcribed retrotransposed loci discovered through comprehensive transcriptome analysis using Paired-End diTags (PETs). Genome Res 2007, 17(6):828-838.

27. Barlund M, Monni O, Weaver JD, Kauraniemi P, Sauter G, Heiskanen M, Kallioniemi OP, Kallioniemi A: Cloning of BCAS3 (17q23) and BCAS4 (20q13) genes that undergo amplification, overexpression, and fusion in breast cancer. Genes Chromosomes Cancer 2002, 35(4):311-317.

28. Hampton OA, Den Hollander P, Miller CA, Delgado DA, Li J, Coarfa C, Harris RA, Richards S, Scherer SE, Muzny DM, Gibbs RA, Lee AV, Milosavljevic A: A sequence-level map of chromosomal breakpoints in the MCF-7 breast cancer cell line yields insights into the evolution of a cancer genome. Genome Res 2009, 19(2):167-177.

29. McAvoy S, Ganapathiraju SC, Ducharme-Smith AL, Pritchett JR, Kosari F, Perez DS, Zhu Y, James CD, Smith DI: Non-random inactivation of large 
common fragile site genes in different cancers. Cytogenet Genome Res 2007, 118(2-4):260-269.

30. Bradley WE, Raelson JV, Dubois DY, Godin E, Fournier H, Prive C, Allard R, Pinchuk V, Lapalme M, Paulussen RJ, Belouchi A: Hotspots of large rare deletions in the human genome. PLoS One 2010, 5(2):e9401.

31. Pollak C, Hagemeijer A: Abnormalities of the short arm of chromosome 9 with partial loss of material in hematological disorders. Leukemia 1987, 1(7):541-548.

32. Prensner JR, Chinnaiyan AM: Oncogenic gene fusions in epithelial carcinomas. Curr Opin Genet Dev 2009, 19(1):82-91.

33. Kawamata N, Ogawa S, Zimmermann M, Niebuhr B, Stocking C, Sanada M, Hemminki K, Yamatomo G, Nannya Y, Koehler R, Flohr T, Miller CW, Harbott J, Ludwig WD, Stanulla M, Schrappe M, Bartram CR, Koeffler HP: Cloning of genes involved in chromosomal translocations by highresolution single nucleotide polymorphism genomic microarray. Proc Natl Acad Sci USA 2008, 105(33):11921-11926.

Pre-publication history

The pre-publication history for this paper can be accessed here: http://www.biomedcentral.com/1755-8794/4/16/prepub

doi:10.1186/1755-8794-4-16

Cite this article as: Przybytkowski et al.: The use of ultra-dense array CGH analysis for the discovery of micro-copy number alterations and gene fusions in the cancer genome. BMC Medical Genomics 2011 4:16.

\section{Submit your next manuscript to BioMed Central} and take full advantage of:

- Convenient online submission

- Thorough peer review

- No space constraints or color figure charges

- Immediate publication on acceptance

- Inclusion in PubMed, CAS, Scopus and Google Scholar

- Research which is freely available for redistribution

Submit your manuscript at www.biomedcentral.com/submit 